\title{
The Virgin Islands National Information Systems for Health: vision, actions, and lessons learned for advancing the national public health agenda
}

\author{
Irad Potter, ${ }^{1}$ Tracia Petersen, ${ }^{1}$ Marcelo D’Agostino, ${ }^{2}$ Daniel Doane, ${ }^{3}$ \\ Patricia Ruiz, ${ }^{2}$ Myrna Marti, ${ }^{2}$ James Fitzgerald, ${ }^{2}$ Amalia del Riego, ${ }^{2}$ \\ Federico G. de Cosio, ${ }^{2}$ and Marcos Espinal ${ }^{2}$
}

Suggested citation

Potter I, Petersen T, D'Agostino M, Doane D, Ruiz P, Marti M, et al. The Virgin Islands National Information Systems for Health: vision, actions, and lessons learned for advancing the national public health agenda. Rev Panam Salud Publica. 2018;42:e156. https://doi.org/10.26633/RPSP.2018.156

\begin{abstract}
The British Virgin Islands (BVI) Ministry of Health and Social Development (MOHSD) recently identified the need for an updated strategy to advance the country's vision for Information Systems for Health (IS4H) ("Informed decision-making for better health outcomes"). Since the early 1990s, the MOHSD has recognized the importance of having strong conceptual foundations and mechanisms for its information systems, and the need to strengthen the production and use of good-quality health data to enable fulfillment of the territory's health goals. Therefore, in May 2017, BVI requested technical assistance from the Pan American Health Organization (PAHO) to develop a plan/"road map" for strengthening the MOHSD's stewardship capacity for IS4H. This resulted in a bilateral, country-led collaboration between PAHO and the Ministry to carry out two assessments of BVI's National Information Systems for Health (NISH): 1) a rapid assessment to map NISH policy, to develop a short- and medium-term workplan for strengthening and updating it, and 2) a maturity assessment, using PAHO's IS4H Maturity Model tool, to evaluate the implementation of NISH policy thus far and determine next steps. This article describes 1) the steps taken in this bilateral collaboration to update BVI's NISH policy and fine-tune its IS4H vision, including the development of a national plan/road map, and 2) lessons learned.
\end{abstract}

Keywords Information systems; public health; health systems; British Virgin Islands; Caribbean region.

Since the early 1990s, the British Virgin Islands (BVI) Ministry of Health and Social Development (MOHSD) has

\footnotetext{
Ministry of Health and Social Development, Tortola, Virgin Islands.

2 Pan American Health Organization, Washington, D.C., United States of America. Send correspondence to Marcelo D’Agostino, dagostim@paho.org.

International Consultant, Toronto, Canada.
}

recognized the importance of having strong conceptual foundations and mechanisms for its information systems, and the need to strengthen the production and use of good-quality health data to enable fulfillment of the territory's health goals. Therefore, in May 2017, BVI requested technical assistance from the
Pan American Health Organization (PAHO) to develop a plan/"road map" for strengthening the MOHSD's stewardship capacity for Information Systems for Health (IS4H). This report describes BVI's vision for IS4H ("Informed decision-making for better health outcomes") and outlines the progress that has been 
made in updating and strengthening its National Information Systems for Health (NISH) policy, a critical first step in providing a sound foundation for future development of IS4H in the territory.

The bilateral collaboration between the MOHSD and PAHO included 1) a BVI-led rapid assessment of the territory's National Information Systems for Health (NISH), to map NISH policy, to develop a short- and medium-term workplan for strengthening and updating it, and 2) a maturity assessment, using PAHO's IS4H Maturity Model (MM) tool, to evaluate the implementation of NISH policy thus far and determine next steps. The following topics are covered below: 1) an overview of BVI, including its status as a territory of the United Kingdom, the policy environment, the effects of globalization and the challenges it faces from the emergence and reemergence of infectious diseases, and the main concepts of its national health policy (1) and national health reforms (including recognition of health as key to the development of the territory, resulting in a renewed focus on health for all, health promotion, and the health in all policies (HiAP) approach), determinants of health, and integrated health service delivery systems based on primary health care and people-centered care across the life course, and 2) IS4H in the territory, including the rationale and purpose of the NISH rapid assessment and maturity assessment carried out in collaboration with PAHO.
In developing the NISH policy, the following steps were carried out: use of the 2010 World Health Organization (WHO) Health Metrics Network (HMN) assessment tool, to conduct an IS4H situation analysis; implementation of the recommendations of the comprehensive HMN review; review of literature and documents; drafting of the NISH policy document based on stakeholders' inputs; and development of the final version of the policy, through multi-sectoral collaboration, and its submission to the NISH Steering Committee and Cabinet for approval.

\section{OVERVIEW OF BVI}

The BVI or Virgin Islands is a United Kingdom Overseas Territory (UKOT) located in the Caribbean to the east of Puerto Rico. Collectively, the BVI, U.S. Virgin Islands, and Spanish Virgin Islands make up the Virgin Islands archipelago. BVI territory comprises an archipelago of about 50 islands, rocky formations, islets, and keys with a total land mass of $153 \mathrm{~km}^{2}$ (59.3 square miles) spread over 1330 square miles (2). The largest and most populated of these islands are Tortola, Virgin Gorda, Anegada, and Jost Van Dyke.

In 2015, BVI's population was 34232 , with $83 \%$ living on Tortola and $14 \%$ on Virgin Gorda, those born abroad representing approximately $60.3 \%$, and people 60 years and older accounting for $13.3 \%$. Between 1990 and 2015, the population distribution became regressive, with a higher concentration in the middle-aged group compared with younger age groups, which include a large proportion of migrant workers. In 2015, the crude birth rate was estimated at 9.1 births per 1000 population and the crude death rate at 4.7 deaths per 1000 population. Estimated life expectancy in 2015 was 79.8 years (Figure 1) (2).

On 6 September 2017, and again on 20 September 2017, BVI suffered catastrophic damage due to the impact of two Category 5 Hurricanes, Irma and Maria respectively. Despite these challenges, the Government of the Virgin Islands (GVI) remain committed to the territory's national health policy goals (to improve the quality of life and standard of living of the residents of the territory, with "all inhabitants ... able to maximise their opportunities for health and well-being as key resources for life and development" (1)) and the IS4H vision ("Informed decision-making for better health outcomes").

\section{National Health Policy and health reforms}

In addition to implementing national health policy goals to achieve its IS4H vision, BVI has embarked on an ambitious program of health reform. This includes the formation of the British Virgin Islands Health Services Authority (BVIHSA) in 2005 and the commissioning of the National Health Insurance system in January 2016. Work continues on

\section{FIGURE 1. Distribution of national population by age and sex, British Virgin Islands, 1991 and 2015}

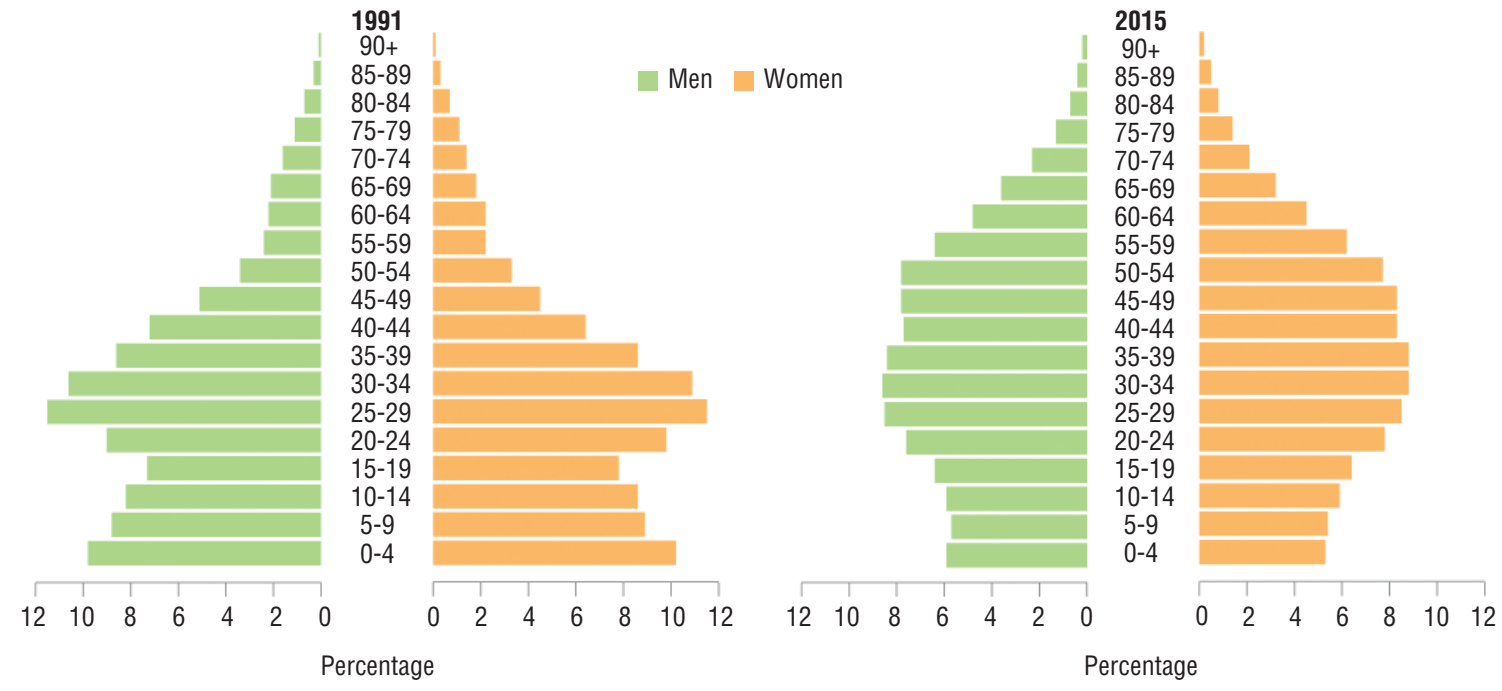

Source: (2); http://www.paho.org/salud-en-las-americas-2017/wp-content/uploads/2017/02/population-bvi-en.png 
the redevelopment of the public health infrastructure. A new hospital was commissioned in 2014, and the district clinic system is being reorganized, with planned reduction in the number of units and the development of polyclinics, to serve larger geographic areas and populations with more complicated health conditions. In May 2017, the territory, with the support of PAHO, began to develop multiple road maps for achieving goals in health and health-related areas, recognizing that the goals of universal access to health and universal health coverage (UHC) ("health for all") could not be realized without advancing multiple strategic lines across different sectors, as outlined in the PAHO strategy for universal access to health and universal health coverage (3). Under strategic line 2 ("Strengthening stewardship and governance") (3), expanding and strengthening the leadership role of the MOHSD and expanding its technical capacity for stewardship of IS4H were identified as key actions and became the focus of the revitalization of BVI's health services sector, based on primary health care.

\section{INFORMATION SYSTEMS FOR HEALTH (IS4H)}

In February 2012, BVI participated in an country situation analysis (CSA) on IS4H, using the WHO HMN tool, along with 16 other countries/territories (Anguilla, Antigua and Barbuda, Bahamas, Barbados, Belize, BVI, Dominica, Grenada, Guyana, Jamaica, Montserrat, St. Kitts and Nevis, St. Lucia, St. Vincent and the Grenadines, Suriname, Trinidad and Tobago, and Turks and Caicos Islands). In June 2015, the CSA was repeated, using the same tool, without changing any of its 18 assessment domains, but with minor modifications to the criteria for health information services (HIS) resources to highlight key components (Table 1). The modifications were related to the business process, change management strategy, data dictionary, data collection and front-end use, reporting module, and governance structure. A total of 14 countries/territories participated in the second CSA (all of the countries from the first CSA except Montserrat and St. Kitts and Nevis).

\section{The Virgin Islands NISH policy}

BVI's NISH policy was developed as a result of teamwork and collaboration

TABLE 1. WHO HMN ${ }^{\mathrm{a}}$ tool domains and areas of assessment for situation analysis of Information Systems for Health (IS4H) in 16 Caribbean countries/territories ${ }^{\mathrm{b}}$ conducted by the Pan American Health Organization, 2015

\begin{tabular}{ll}
\hline Domain & Assessment area \\
\hline Leadership \& coordination & 1. Health information system (HIS) assessments and national HIS \\
& plans \\
& 2. National health strategic planning \\
& 3. Governance and decision-making for HIS \\
& 4. Health system architecture \\
& 5. National HIS architecture and current state of information and \\
& communication technology (ICT) solutions \\
Information policies & 6. Legislative, regulatory and policy framework \\
Financial and human resources & 7. Finance \\
& 8. Human resources \\
Infrastructure & 9. ICT infrastructure \\
& 10. ICT solutions/applications-selection \\
& 11. ICT solutions/applications-implementation \\
& 12. ICT solutions/applications-adoption \\
13. ICT solutions/applications-operations/use \\
14. Data storage \\
15. Data quality \\
16. Data processing and compilation \\
Information dissemination and use
\end{tabular}

Source: Unpublished situation analysis carried out by BVI and PAHO as part of the Caribbean Sub-Regional HIS

Strengthening Framework.

${ }^{a}$ World Health Organization Health Metrics Network.

${ }^{\mathrm{b}}$ Anguilla, Antigua and Barbuda, Bahamas, Barbados, Belize, British Virgin Islands, Dominica, Grenada, Guyana, Jamaica, Montserrat, St. Kitts and Nevis, St. Lucia, St. Vincent and the Grenadines, Suriname, Trinidad and Tobago, and Turks and Caicos Islands.

across various agencies/sectors, both public and private (4). This was an important step in gathering information about data collection analysis and information generation, to help ensure the diversity of the health data sources and contribution of each sector was recognized, and to acknowledge the HiAP initiative (5). The multi-sectoral workshop helped create awareness and strengthen the network involved in the NISH. The result was buy-in and commitment to improving the collection, flow, analysis, and sharing of health-related data. The process for developing the NISH policy involved consultation with stakeholders, a literature review, and consultation and review with PAHO. The final draft of the NISH policy was submitted to and approved by the Cabinet in the Virgin Islands.

The NISH policy was designed to guide the health sector in developing and implementing integrated information systems that will produce goodquality data and information for decision-making and ensure its availability to help allocate resources efficiently and improve health system management, the quality of health care, and population health. It also aims to equip health care managers at all levels with the tools to access information that will enable them to address individual and population health needs, achieve national objectives, and measure health system performance. The NISH policy therefore calls for the provision of infrastructure and human resource capacity for the collection and processing of data and promotes the use of information for evidence-informed decision-making at all levels.

\section{Renewed strategy for IS4H}

Since the early 1990s, the MOHSD has recognized the need to strengthen the production and use of good-quality health information services (IS4H) to enable fulfillment of the territory's health goals. At that time, the territory was one of 10 Eastern Caribbean countries involved in the PAHO-executed Caribbean Information System for Health project, which focused on the computerization of HIS in participating countries. The project impact was low as the modules developed were fragmented and did not take into account the rapid changes in information and communication technology (ICT). 
Implementation in the BVI was limited to ruling out the communicable diseases module, which was fraught with problems. The MOHSD therefore focused on documenting 1) the type of governance that would be needed to attain its vision for IS4H, along with the legal, technical and administrative requirements; 2) its data management policy and guidelines, and information architecture; and 3) required information products to ensure a strong foundation on which future computerization efforts could be built.

\section{PAHO-BVI collaboration}

Rapid assessment of NISH. In May 2017, the MOHSD asked PAHO for technical support to conduct a rapid assessment of the NISH, led by BVI, to develop a short- and medium-term workplan for strengthening IS4H capacity. The rapid assessment process was divided into six strategic areas, as shown in Table 2.

The rapid assessment focused on 1) the capacity of the MOHSD and its network of national stakeholders to effectively plan, manage, and sustain the use of IS4H in order to generate information for decision-making, support the effective delivery of health services, and enable high-quality comprehensive health care, and 2) key components of the NISH, including document review, governance, strategies and plans, legislation and policy, financial sustainability, human resources, data management and quality processes, data analysis capabilities, business and clinical workflow and processes, project and change management, and information technology (IT) platforms and infrastructure.

The rapid assessment methodology included virtual meetings, document review, the intensive three-day CSA described above, and review of gaps, capacities, and opportunities related to strengthening country capacity for IS4H. It was designed to give the country a "snapshot" of the current situation, including capacity and gaps, and proposed a high-level road map. It also provided initial directions for the country across a range of 18 domains related to IS4H (Table 3). Key findings of the assessment were as follows: 1) the presence of the NISH policy was a strength, as it included a clear description of the importance of IS4H for health systems strengthening; 2) key draft legislation needed to

TABLE 2. Six strategic areas addressed in the Pan American Health Organization (PAHO)-British Virgin Islands (BVI) rapid assessment of BVI's National Information Systems for Health (NISH) policy, 2017

\begin{tabular}{ll}
\hline Strategic area & Main objective \\
\hline $\begin{array}{ll}\text { 1. Governance and management } & \text { To ensure strategic and coordinated development of } \\
\text { BVI's NISH policy }\end{array}$ \\
$\begin{array}{ll}\text { 2. Organizational structure, roles, and human } \\
\text { resource capacity }\end{array}$ & $\begin{array}{l}\text { To develop and strengthen the necessary skill sets and } \\
\text { administrative resources to support and sustain }\end{array}$ \\
$\begin{array}{ll}\text { 3. Enabling strategies, legislation, policies, } \\
\text { and standard operating procedures (SOPs) }\end{array}$ & $\begin{array}{l}\text { To ensure the NISH policy's legal, administrative, and } \\
\text { technical framework supports its stated direction and } \\
\text { effective planning, implementation, and evaluation }\end{array}$ \\
$\begin{array}{ll}\text { 4. Appropriate, reliable, and sustainable } \\
\text { ICT infrastructure }\end{array}$ & $\begin{array}{l}\text { To promote timely and upgrade information and } \\
\text { communication technology (ICT) solutions within the } \\
\text { health system }\end{array}$ \\
$\begin{array}{ll}\text { 5. Data collection and management functions } \\
\text { and processes to support good-quality data }\end{array}$ & To support the standardization of data distribution \\
6. Information generation and knowledge & To improve the quality of information and the timely \\
sharing & production of information analysis and dissemination \\
\hline
\end{tabular}

Source: Compiled by the authors based on an unpublished report by PAHO-BVI.

TABLE 3. Documents reviewed in the Pan American Health Organization-British Virgin Islands (BVI) rapid assessment of BVI's National Information Systems for Health (NISH) policy, by type, 2017

\begin{tabular}{|c|c|}
\hline Document type & Description \\
\hline Strategic and other plans & $\begin{array}{l}\text { - Strategic plan ("road map") for implementation of BVI's NISH policy } \\
\text { (current or in-progress drafts) } \\
\text { - IS4H strategic plan } \\
\text { - e-Government strategic plan or project plans } \\
\text { - Vertical Program priorities, plans } \\
\text { - Plans for census, vital registration/statistics } \\
\text { - Plan or commitments related to other national or international efforts (e.g., } \\
\text { Sustainable Development Goals (SDGs), HIV, noncommunicable diseases } \\
\text { (NCDs), maternal and child health (MCH), etc.) } \\
\text { - Recent evaluations/assessments }\end{array}$ \\
\hline Governance documents & $\begin{array}{l}\text { - Governance structures and terms of reference for committees/working } \\
\text { groups/advisory bodies } \\
\text { - Organizational structure } \\
\text { - Any relevant human resource (HR) documents (e.g., staffing numbers/ } \\
\text { competency framework/HR plans) }\end{array}$ \\
\hline Policies and legislation & $\begin{array}{l}\text { - Related policies or legislation (e.g., personal health information protection, } \\
\text { medical records, information technology) }\end{array}$ \\
\hline Technical documentation & $\begin{array}{l}\text { - Software/solutions inventory } \\
\text { - Technical/network architecture } \\
\text { - BVI Health Services Authority (HSA) and other system documents (training } \\
\text { manuals, standard operating procedures (SOPs)) } \\
\text { - Service level agreements/contracts with vendor(s) }\end{array}$ \\
\hline $\begin{array}{l}\text { Information architecture } \\
\text { documentation }\end{array}$ & $\begin{array}{l}\text { - Data management policies, guidelines, standards } \\
\text { - Data dictionary } \\
\text { - Indicator compendiums } \\
\text { - Data flows } \\
\text { - Data standards }\end{array}$ \\
\hline Information products & $\begin{array}{l}\text { - Chief Medical Officer (CMO) reports } \\
\text { - Epidemiology (EPI) reports } \\
\text { - Weekly / monthly administrative reports (e.g., hospital and clinic utilization } \\
\text { statistics, etc.) } \\
\text { - Special reports (e.g., status of a specific disease, health behaviors, etc.) }\end{array}$ \\
\hline
\end{tabular}

Source: Compiled by the authors based on the rapid assessment process.

be reviewed and strengthened; 3) the NISH Steering Committee needed to be reestablished to lead coordination and collaboration between partners; 4) a change in management capacity building was needed; and 5) there was an opportunity to leverage the leadership of the MOHSD to move e-government 
forward by framing IS4H within the national e-government strategy.

Strategic partnership with PAHO. PAHO and the MOHSD also collaborated to develop a national plan / road map (Figure 2) within the context of PAHO's updated strategic framework for the IS4H model (Figure 3).

PAHO's updated framework for the IS4H model. PAHO's vision for the IS4H initiative (6-9) is to strengthen universal access to health and universal health coverage through interconnected and interoperable health-related systems that ensure effective and efficient access to good-quality data, strategic information, and ICT tools for decision-making and improved health outcomes. The main goal of this updated framework is to implement a better decision- and policymaking mechanism through health systems that ensure universal, free, and timely access to data and strategic information using the most cost-effective ICT tools. It also seeks to establish a mechanism for managing interoperable systems with open data that come from different sources and are used ethically to generate strategic information for the benefit of public health.

The implementation of PAHO's updated framework for IS4H in the Caribbean was presented and discussed in 2016 at a high-level ministerial meeting in Jamaica that engaged the 17 Caribbean countries, regional entities and experts, and UN agencies and other development partners. The meeting was co-hosted with the Ministry of Health of Jamaica (10). This action has motivated other countries in the Caribbean to request technical cooperation to follow this innovative path. In addition to the updated framework, the Caribbean Council for Human and Social Development (COHSOD) endorsed an official road map of actions in the Caribbean subregion for the period 2017-2020.

IS4H-MM: PAHO's Maturity Model assessment tool. The IS4H-MM is a tool for assessing the maturity level of IS4H in an organization and the capacity to operate, interact with, and benefit from it (Table 4). The IS4H-MM assessment analyzes the maturity of information management processes, information governance readiness, open government initiatives, and knowledge management
FIGURE 2. Timeline of a Pan American Health Organization (PAHO)-British Virgin Islands collaboration to 1) assess BVI's health information systems (HIS); 2) develop a National Information Systems for Health (NISH) policy, using PAHO's Information Systems for Health (IS4H) framework; 3) pilot-test the IS4H Maturity Model (IS4H-MM) assessment tool, and develop/implement a road map to attain policy goals, 20122017

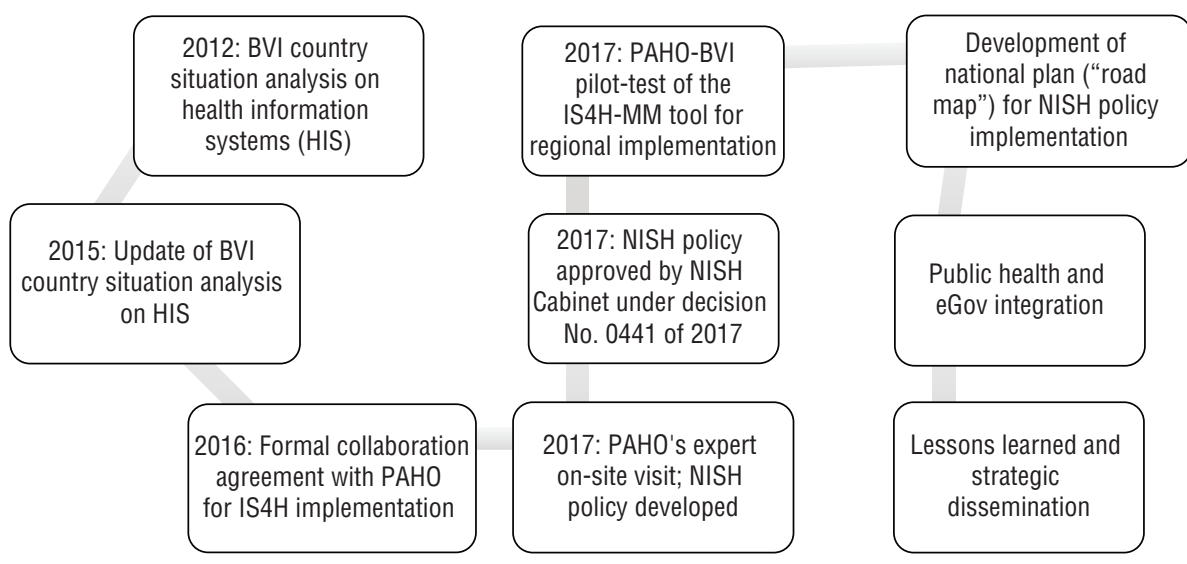

Source: Compiled by the authors based on the PAHO-BVI strategic collaboration.

FIGURE 3. Updated strategic framework for the Pan American Health Organization Information Systems for Health (IS4H) model: operational view, 2018

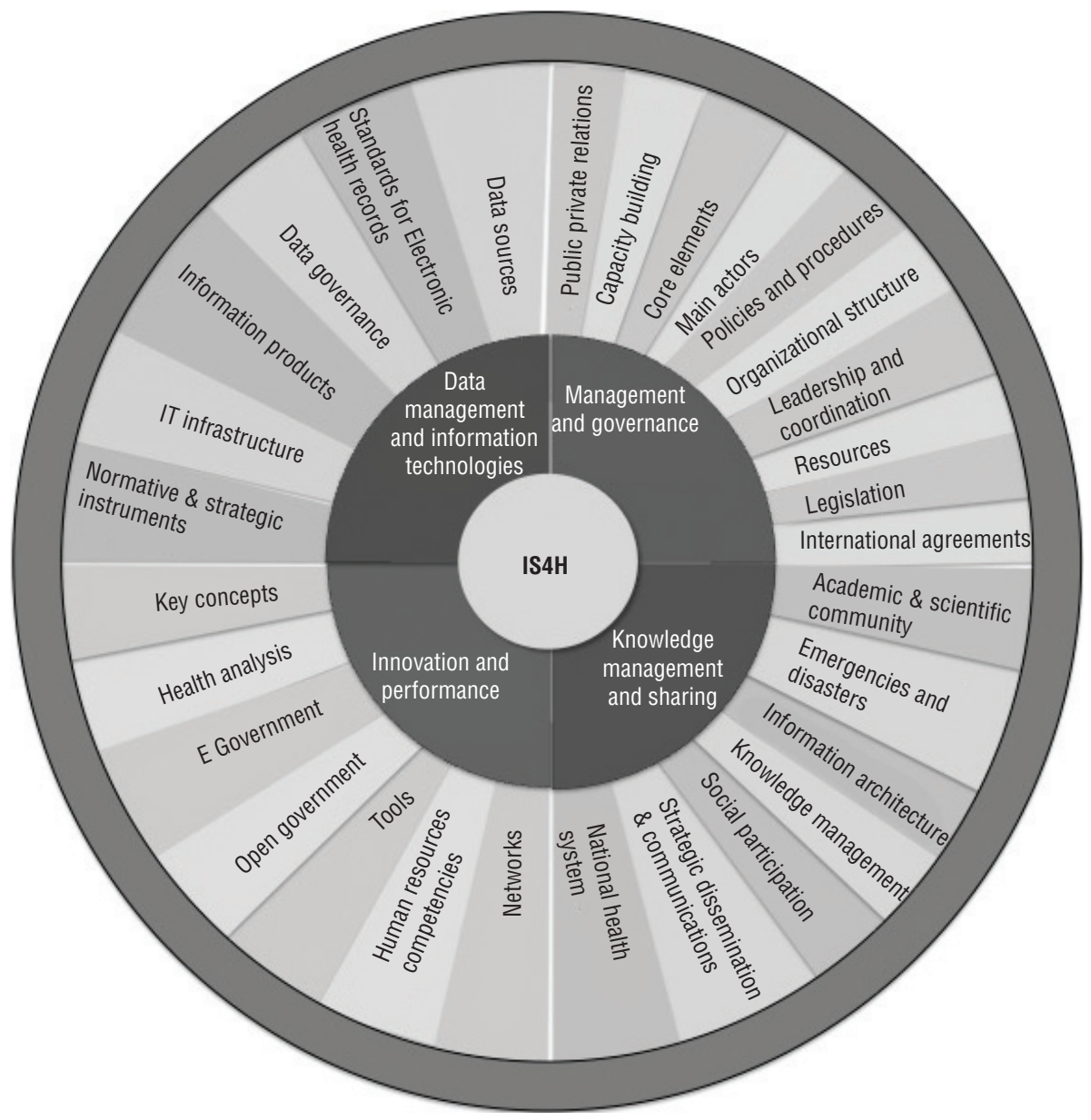

Source: (9). 
TABLE 4. Five levels of assessment of the Pan American Health Organization Information Systems for Health Maturity Model (IS4H-MM) tool for evaluating progress in implementing health information systems policy, 2018

\begin{tabular}{|c|c|}
\hline IS4H-MM assessment level & Description \\
\hline $\begin{array}{l}\text { Public health information } \\
\text { organized } \\
\text { (Level 1) }\end{array}$ & $\begin{array}{l}\text { Some form of data is collected electronically across health organizations and among } \\
\text { stakeholders of that region's health system. The processes of entering health data are } \\
\text { usually ad hoc, and the environment is not stable. Success depends on individuals } \\
\text { within the organization, rather than the use of proven processes. Maturity Level } 1 \\
\text { organizations produce health information products and services that require intensive } \\
\text { work and use of resources. Datasets are often not accessible for other purposes. }\end{array}$ \\
\hline $\begin{array}{l}\text { Public health information } \\
\text { managed } \\
\text { (Level 2) }\end{array}$ & $\begin{array}{l}\text { There is evidence of health data management processes and best practices (e.g., } \\
\text { standards, organizational structures, policies, procedures, and technology). There } \\
\text { are legal, ethical, and business practices protecting individuals and serving } \\
\text { stakeholders to advance the public good. Maturity Level } 2 \text { organizations are } \\
\text { focused on using good-quality data to support decision-making to improve access } \\
\text { to health and health outcomes. Datasets are readily available and information } \\
\text { products are efficiently produced. }\end{array}$ \\
\hline $\begin{array}{l}\text { Public health decisions based } \\
\text { on information } \\
\text { (Level 3) }\end{array}$ & $\begin{array}{l}\text { All essential information is readily accessible. Organizations have the necessary } \\
\text { workforce, capacity, legal and ethical framework, and technology infrastructure. } \\
\text { Maturity Level } 3 \text { organizations make informed decisions based on information and } \\
\text { the ethical use of data. }\end{array}$ \\
\hline $\begin{array}{l}\text { Information governance and } \\
\text { KM implemented } \\
\text { (Level 4) }\end{array}$ & $\begin{array}{l}\text { There are continuous improvements to information assets by ensuring that data } \\
\text { and content are accurate, reliable, up-to-date, consistent, and ready to use. } \\
\text { Knowledge management (KM) techniques are in place and refer to processes } \\
\text { within a public health organization. Maturity Level } 4 \text { organizations have policies, } \\
\text { procedures, processes, and controls implemented to manage information at a } \\
\text { health organizational level, supporting regulatory, legal, risk, environmental, and } \\
\text { operational requirements, and a consistent and logical framework for stakeholders } \\
\text { to handle data through their information governance policies and procedures. }\end{array}$ \\
\hline $\begin{array}{l}\text { IS4H implemented } \\
\text { (Level 5) }\end{array}$ & $\begin{array}{l}\text { The implementation of IS4H is a sustained, integrated effort to have good-quality } \\
\text { data and strategic information free and publicly available for better policy and } \\
\text { decision-making processes in public health systems. Maturity Level } 5 \text { organizations } \\
\text { achieve the convergence of interconnected and interoperable systems. }\end{array}$ \\
\hline
\end{tabular}

Source: Compiled by the authors based on data from (9).

TABLE 5. Major accomplishments in health reforms, British Virgin Islands (BVI), 2000-2017

\begin{tabular}{ll}
\hline Period & Action \\
\hline $\mathbf{2 0 0 0 - 2 0 0 8}$ & Focus on health information and public health surveillance \\
$\mathbf{2 0 0 9}$ & $\begin{array}{l}\text { Health Surveillance Officer hired to allow Health Information Officer to increase focus on } \\
\text { health information management in order to improve national capacity to collect, store, } \\
\text { and analyze health data }\end{array}$ \\
& $\begin{array}{l}\text { Implementation of electronic notification of births and deaths } \\
\mathbf{2 0 1 1}\end{array}$ \\
$\mathbf{2 0 1 2}$ & $\begin{array}{l}\text { Implementation of integrated electronic records system and range of electronic data } \\
\text { collection tools }\end{array}$ \\
$\mathbf{2 0 1 2}$ & First BVI country situation analysis on health information systems (HIS) \\
$\mathbf{2 0 1 5}$ & Second BVI country situation analysis on HIS \\
$\mathbf{2 0 1 6}$ & Drafting of legal framework for health information privacy and protection \\
$\mathbf{2 0 1 7}$ & National Information Systems for Health (NISH) policy approved \\
$\mathbf{2 0 1 7}$ & National plan ("road map") for NISH policy implementation drafted \\
$\mathbf{2 0 1 7}$ & Pan American Health Organization Information Systems for Health Maturity Model (IS4H-MM) \\
& tool pilot-tested for regional implementation \\
\hline
\end{tabular}

Source: Compiled by the authors based on the BVI health reform timeline.

process adoption. The BVI MOHSD made the decision to support PAHO in piloting this new tool for future implementation in the Americas region. Thanks to this pilot test, countries in the region-and worldwide-could benefit from implementing a tool proven in previous analyses of the maturity level of IS4H in health institutions.

\section{Timeline of BVI's progress in IS4H}

Important progress was made in BVI's IS4H assessment process with limited resources but high-level political commitment. A series of steps were carried out that will provide the country with a sustainable base for future developments and investments in IS4H. The most important ones are listed in Table 5 .

\section{Lessons learned}

The process of identifying and analyzing lessons learned from the PAHO-BVI collaboration on IS4H supported effective managerial actions based on facts and evidence (11), and led to the following conclusions by BVI stakeholders: 1) the NISH will not be a quick fix and will require collaboration, time, and money; 2) it is critical to first develop the legal, technical, and managerial framework as well as key informatics processes and tools, and to define roles and responsibilities, establish a governance structure, and ensure commitment to capacity building and data sharing, in order to help support interoperability and reduce fragmentation in data management practices; 3) data quality will improve with timely ICT integration, data-sharing arrangements, and technological innovations, and a national electronic data repository will reduce the risk of information silos.

\section{The way forward}

Future objectives include the following: 1) development of a NISH Strategic Plan that provides a road map with timelines; 2) development of tools, standards, and guidelines to enhance capacity to collect accurate, timely, and reliable data, utilize health data more efficiently, and effectively communicate risk and health knowledge to colleagues and other practitioners; 3 ) implementation of capacity building in knowledge management methodologies; 4) development of an electronic integrated data repository that will combine data from different sources, allow for both collection and management of information, and enable wide distribution of data; 5) ensure convergence between the implementation of the NISH Strategic Plan and Policy under the principles of the Open Government Partnership (12) and following the eight principles of Open Government Data (13).

Caribbean Community (CARICOM) member states have long identified IS4H 
as a priority for advancing public health in the region, and more recently for moving toward universal access to health and universal health coverage (14) and, ultimately, the achievement of the Sustainable Development Goals (SDGs) (15). While CARICOM countries' IS4H are at different levels of maturity, each country has identified a common goal and framework for advancing public health in the region. The implementation of BVI's IS4H initiative seeks to enhance innovation, forecasting, health analysis, collaboration, and coordination territory-wide by defining and adopting standards for interoperability that allow for cost-effective ICT applications, in order to exchange and make use of information from all countries and work together within and across organization boundaries.

\section{Limitations}

This report documents two specific evaluation processes carried out with a new assessment tool in one country.
Further elaboration, based on future assessments, as the PAHO Maturity Model tool is applied and implemented elsewhere, will strengthen/confirm the lessons learned from this experience. Some of the information products resulting from this evaluation are not yet finalized-including the legal framework, which is still in draft form-which has impeded full implementation of the NISH policy, so it is difficult to draw conclusions about their possible impact. Additional research on the main output of these assessments-the NISH policy and its vision-will be carried out by BVI after two years of implementation to measure the impact.

\section{Conclusions}

The success in BVI's collaboration with PAHO and the two health systems assessments is the progress made in identifying the critical role of IS4H in the development of the health sector as a vehicle for realizing the goal of BVI's National Health Policy and Strategic
Plan. The approval of the NISH policy and continuing work toward its implementation, and the piloting and adaption of the IS4H Maturity Model as a guide and relevant tool for improving health information systems in the BVI, has positioned the territory as a leader and effective participant in the Caribbean drive to improve knowledge management and integrate ICT and other technologies as key resources for health and development.

Acknowledgments. The authors wish to thank Godfrey Xuereb, Jessie SchuttAine, Peter Cowley, Casimiro Canha Cavaco Diaz, Jose Francisco Salm, Ian Brooks, and Paula Otero for their invaluable support and contributions.

\section{Conflict of interests. None.}

Disclaimer. Authors hold sole responsibility for the views expressed in the manuscript, which may not necessarily reflect the opinion or policy of the RPSP / $\mathrm{PAJPH}$ and/or PAHO.

\section{REFERENCES}

1. Government of the Virgin Islands. National Health Policy and Strategic Plan [Internet]. Tortola: Ministry of Health and Social Development, GVI; 2018. Available from: http://www.bvi.gov.vg/content/ ministry-health-and-social-development Accessed on 3 March 2018.

2. Pan American Health Organization. Health in the Americas 2017. Washington: PAHO; 2017. Available from: http:// www.paho.org/hia2017 Accessed on 3 March 2018.

3. Pan American Health Organization. Strategy for universal access to health and universal health coverage. Washington: PAHO; 2014. (CD53/5, Rev. 2). Available from: http://www.paho.org/hq/index. php?option $=$ com_docman \& task $=$ doc $_{-}$ download \& gid $=27312 \&$ Itemid $=270 \&$ lang=en

4. Government of the Virgin Islands: National Information Systems for Health Policy. Washington; 2018.

5. World Health Organization. Health in all policies (HiAP) framework for country action. Geneva:WHO;2014. Availablefrom: http:/ / www.who.int/ cardiovascular diseases /140120HPRHiAPFramework. pdf Accessed on 13 March 2018.

6. United Nations Secretary General Independent Expert Advisory Group on a Data Revolution for Sustainable Development. A world that counts: mobilizing the data revolution for sustainable development. New York: UNSG-IEAG;
2014. Available from: http://www. undatarevolution.org/report/ Accessed on 4 October 2016.

7. Bunge M. How does it work? The search for explanatory mechanisms. Philos Soc Sci. 2004;34(2):182-210. doi:10.1177/0048393103262550.

8. Bunge M. Emergence and convergence: qualitative novelty and the unity of knowledge. Toronto: University of Toronto Press; 2003.

9. Pan American Health Organization. Information Systems for Health [Internet]. Washington: PAHO; 2018. Available from: https://www.paho.org/ish Accessed on 22 May 2018.

10. Pan American Health Organization. Caribbean countries to discuss information systems for health to increase the effectiveness of health-related decisionmaking and improve the delivery of health care [Internet]. Washington: PAHO; 2016. Available from: https://www. paho.org/ocpc/index.php?option $=\mathrm{com}_{-}$ content\&view $=$ article \&id $=404: \mathrm{caribb}$ ean-countries-to-discuss-informationsystems-for-health-to-increase-theeffectiveness-of-health-related-decisionmaking-and-improve-the-delivery-ofhealth-care\&Itemid $=1540$ Accessed on 3 March 2018

11. Pan American Health Organization. Methodologies for information sharing and knowledge management in health [Internet]. Washington: PAHO; 2015.
Available from: http://www.paho.org/ hq/index.php?option=com_content\&vie $\mathrm{w}=$ article\&id $=7381 \&$ Itemid $=1430 \&$ lang $=$ en Accessed on 1 March 2018.

12. Open Government Partnership. About OGP [Internet]. Washington: OGP 2017. Available from: https://www. opengovpartnership.org/about/aboutogp Accessed on 22 November 2017.

13. Open Government Data. The 8 principles of Open Government Data [Internet]. 2017. Available from: https:// opengovdata.org/ Accessed on 22 November 2017.

14. Pan American Health Organization. Strategy for universal health coverage. Washington: PAHO; 2014. Available from: http://iris.paho.org/ xmlui/handle/123456789/4186 Accessed on 22 November 2017.

15. United Nations. Sustainable development goals [Internet]. New York: UN Sustainable Development Knowledge Platform; 2018. Available from: https:// sustainabledevelopment.un.org/sdgs Accessed on 3 March 2018.

Manuscript submitted 18 March 2018. Revised version accepted for publication on 31 May 2018. 
RESUMEN

Sistemas Nacionales de Información para la Salud de las Islas Vírgenes: visión, acciones y lecciones aprendidas para avanzar en la agenda nacional de salud pública

Palabras clave
El Ministerio de Salud y Desarrollo Social de las Islas Vírgenes Británicas identificó recientemente la necesidad de tener una estrategia actualizada para avanzar la visión del país en el ámbito de los sistemas de información para la salud (IS4H) ("Toma de decisiones informadas para obtener mejores resultados de salud"). Desde principios de la década de 1990, el Ministerio ha reconocido la importancia de tener sólidos fundamentos conceptuales y mecanismos para sus sistemas de información, así como la necesidad de fortalecer la producción y el uso de datos de salud de buena calidad para permitir el cumplimiento de los objetivos de salud del territorio. En este contexto, en mayo de 2017 las Islas Vírgenes Británicas solicitaron la asistencia técnica de la Organización Panamericana de la Salud (OPS) para desarrollar un plan u "hoja de ruta" para fortalecer su capacidad de administración en el ámbito de los IS4H. Esto resultó en una colaboración bilateral, dirigida por el país, entre la OPS y el Ministerio para llevar a cabo dos evaluaciones de los Sistemas Nacionales de Información para la Salud: 1) una evaluación rápida para mapear la política de estos sistemas, y desarrollar un plan de trabajo a corto y mediano plazo para fortalecerlos y actualizarlos y 2) una evaluación de madurez, utilizando la herramienta Modelo de Madurez de IS4H de la OPS, para evaluar la implementación de la política de Sistemas Nacionales de Información para la Salud hasta el momento y determinar los próximos pasos. Este artículo describe 1) los pasos dados en esta colaboración bilateral para actualizar la política de Sistemas Nacionales de Información para la Salud de las Islas Vírgenes Británicas y ajustar su visión del IS4H, incluido el desarrollo de un plan nacional u hoja de ruta, y 2) las lecciones aprendidas durante este proceso.

Sistemas de información; salud pública; sistemas de salud; Islas Vírgenes Británicas; región del Caribe.

RESUMO O Ministério da Saúde e Desenvolvimento Social das Ilhas Virgens Britânicas identificou recentemente a necessidade de uma estratégia atualizada para avançar a visão do país para os Sistemas de Informação para a Saúde (IS4H) ("Tomada de decisão informada para melhores resultados de saúde"). Desde o início dos anos 1990, o Ministerio reconheceu a importância de ter fortes fundamentos conceituais e mecanismos para seus sistemas de informação, e a necessidade de fortalecer a produção e o uso de dados de boa qualidade em saúde para permitir o cumprimento das metas de saúde do território. Portanto, em maio de 2017, as Ilhas Virgens Britânicas solicitaram assistência técnica da Organização Pan-Americana da Saúde (OPAS) para desenvolver um plano/roteiro para o fortalecimento da capacidade de administração do Ministerio para a IS4H. Isso resultou em uma colaboração bilateral entre a OPAS e o Ministério, liderada pelo país, para conduzir duas avaliações dos Sistemas Nacionais de Informação para a Saúde das Ilhas Virgens Britânicas: 1) uma avaliação rápida para mapear a política do Sistemas Nacionais de Informação para a Saúde, e desenvolver uma estratégia de curto e médio prazo e um plano de trabalho para fortalecê-los e atualizá-los; e 2) uma avaliação de maturidade, utilizando a ferramenta Modelo de Maturidade IS4H da OPAS, para avaliar a implementação da política do Sistemas Nacionais de Informação para a Saúde até o momento e determinar os próximos passos. Este artigo descreve 1) os passos dados nessa colaboração bilateral para atualizar a política de Sistemas Nacionais de Informação para a Saúde das Ilhas Virgens Britânicas e ajustar sua visão de IS4H, incluindo o desenvolvimento de um plano nacional/roteiro, e 2) as lições aprendidas neste processo.

Palavras-chave

Sistemas de informação; saúde pública; sistemas de saúde; Ilhas Virgens Britânicas; região do Caribe. 